\title{
LAMA PENGERINGAN JAGUNG EFEK RUMAH KACA DENGAN TAMBAHAN MEDIA PENYIMPAN PANAS
}

\author{
Yunita Djamalu' ${ }^{1)}$ Evi Sunarti Antu ${ }^{2)}$ \\ ${ }^{1}$ Program Studi Mesin dan Peralatan Pertanian, Politeknik Gorontalo ${ }^{1}$ \\ email: naura@poligon.ac.id \\ ${ }^{2}$ Program Studi Mesin dan Peralatan Pertanian, Politeknik Gorontalo ${ }^{2}$ \\ email: evian@poligon.ac.id
}

\begin{abstract}
ABSTRAK
Pengeringan Efek Rumah Kaca masih jauh dari hasil yang optimal untuk itu dibutuhkan pengembangan untuk memaksimalkan kinerja alat untuk itu di perlukan perancangan alat pengering dengan media penyimpan panas untuk meningkatkan kualitas hasil panen jagung. Pengering efek rumah kaca memiliki 3 bagian utama yaitu ruang pengering pada keadaan tunak, batu sebagai media penyimpan panas dan variasi bukaan cerobong. Dimensi dari pengering ini adalah panjang $1 \mathrm{~m}$, lebar $0,8 \mathrm{~m}$, tinggi $0,6 \mathrm{~m}$, tebal kaca $5 \mathrm{~mm}$, tebal plat alumunium $3 \mathrm{~mm}$, sudut kemiringan atap $60^{\circ}$, cerobong berdiameter $100 \mathrm{~mm}$ dengan tinggi $300 \mathrm{~mm}$ yang terbuat dari bahan pipa pvc dan batu sebagai penyimpan panas yang berdiameter 40 sampai dengan $50 \mathrm{~cm}$. Mekanisme pembuatan alat ini terdiri dari evaluasi desain, persiapan alat dan bahan, pengerjaan alat dan pengujian alat. Hasil uji coba menunjukan pengering terbaik adalah pada variasi 6 dengan bak pengering alumunium dan bukaan $100 \%$ pada cerobong 2 dengan hasil untuk pengeringan $5 \mathrm{~kg}$ jagung pipilan yang di uji cobakan yang membutuhkan waktu 9 jam waktu pengeringan Suhu ruang tertinggi adalah $62^{\circ} \mathrm{C}$, kadar air setelah pengujian menjadi $12,6 \%$ dari kadar air awal $21 \%$, kelembaban relatif ruang pengering lebih kecil dari pada kelembaban relatif lingkungannya, massa akhir jagung adalah 3,1 kg dari massa awal $5 \mathrm{~kg}$, Qe adalah 2344.51 J/m².s, Mev adalah 1039.19 gram dan efisiensi alat pengering yaitu $85 \%$, sedangkan efisiensi pengeringan terbaik adalah pada variasi 3 yaitu $70 \%$, dan lama penyimpanan terbaik adalah pada variasi 6 dengan panas batu menyimpan panas adalah $34{ }^{\circ} \mathrm{C}$ pada pukul 22.00 WITA.
\end{abstract}

Kata Kunci : Jagung, pengering, batu, kadar air, laju penguapan

\section{ABSTRACT}

Drying of the Greenhouse Effect is still far from the optimum result, therefore development required to maximize the performance of the equipment to design the dryer with heat storage media to improve the quality of corn yield. The greenhouse effect dryer had 3 main parts i.e. drying chamber in steady state, stone as heat storage medium and chimney aperture variation. The dimensions of this drier were the long of $1 \mathrm{~m}$, the wide of $0.8 \mathrm{~m}$, the high of $0.6 \mathrm{~m}$, the thick glass of $5 \mathrm{~mm}$, the aluminum plate thickness of $3 \mathrm{~mm}$, the roof inclination angle of $60^{\circ}$, the diameter flake of $100 \mathrm{~mm}$ with height made of $300 \mathrm{~mm}$ with material PVC and stone as heat storage with diameter of 40 to $50 \mathrm{~cm}$. The mechanism of manufacture of this tool consisted of design evaluation, preparation of tools and materials, tool workmanship and tool testing. The experimental results showed the best drying was in variation 6 with aluminum drying bath and 100\% opening in stack 2 with the result for $5 \mathrm{~kg}$ drying of corn pipe in the test which required 9 hours of drying time. The highest room temperature was $62^{\circ} \mathrm{C}$, the water content after the test became $12.6 \%$ of the initial moisture content of $21 \%$, the relative humidity of the dryer room was smaller than the relative humidity of the environment, the final mass of the maize was $3.2 \mathrm{~kg}$ of the initial mass of $5 \mathrm{~kg}$, Qe was $2344.51 / \mathrm{m}^{2} . \mathrm{s}$, Mev was 1039.19gram and dryer efficiency was $85 \%$, while the best drying efficiency was of variation 3 that was $70 \%$, and the best storage duration is on variation 6 with hot stones storing heat is $34{ }^{\circ} \mathrm{C}$ at 22.00 WITA.

Keywords: Corn, dryer, stone, moisture content, evaporation rate

\section{PENDAHULUAN}

Jagung merupakan komoditi unggulan di daerah Gorontalo. Menurut data Dinas Pertanian dan Ketahanan Pangan Pemerintah Provinsi Gorontalo, produksi jagung tahun 2011 sebesar 605.781 ton pipilan kering, mengalami penurunan 73.386 ton (10,81 persen) dibandingkan produksi tahun 2010 . Dari data tersebut menunjukkan bahwa cukup banyak petani jagung di Gorontalo yang merugi dikarenakan cuaca yang tidak pasti disamping gangguan hama dan wereng.

Masyarakat Indonesia khususnya di daerah Gorontalo mengeringkan jagung dengan menggunakan cara alami, yakni dengan menjemur langsung dibawah sinar matahari. Hal ini sangat bergantung pada musim/cuaca. Saat musim 
penghujan tiba, Jagung yang dijemur tidak bisa kering dalam waktu tiga hari seperti saat musim panas. Hal tersebut cukup mengkhawatirkan bagi petani karena hasil panen mereka tidak bisa dijual cepat atau mungkin tidak bisa dijual sama sekali, sedangkan para petani membutuhkan hasil

penjualan panen untuk membeli bibit baru, penggantian biaya penjemuran, dan membayar pekerja kebun.

Salah satu solusi dari permasalahan tersebut adalah pengeringan dengan menggunakan alat pengering alternatif Efek rumah kaca. Konsep dari alat pengering Efek Rumah Kaca adalah dengan menjebak udara panas didalam ruang pengering yang terbuat dari bahan kaca, sehingga bahan yang akan dikeringkan menerima panas yang lebih tinggi dan waktu memanaskan bahan yang lebih lama.

Penelitian ini akan menganalisa laju pengeringan yang terjadi dalam pengering buatan tipe efek rumah kaca dengan variasi tambahan batu sebagai media penyimpan panas sehingga didapatkan lama penyimpanan panas dan laju pengeringan yang efektif, dari penelitian terdahulu telah didapatkan bahwa semakin besar bukaan cerobong maka akan mempercepat proses pengeringan karena tidak terjadi kondensasi didalam ruang pengering namun suhu didalam ruang pengering akan relatif turun pada pukul 17.00 untuk itu perlu adanya media untuk penyimpanan panas. Target penelitian yakni untuk memperkecil tingkat kerugian pada petani jagung yang diakibatkan oleh perubahan cuaca khususnya saat musim hujan dan menambah suhu panas yang tersimpan dalam ruang pengering. Selain itu, penelitian ini juga akan menjadi acuan dalam merancang pengering buatan kondisi tunak sehingga bisa meningkatkan kualitas produk hasil pertanian dan perikanan di Provinsi Gorontalo dengan waktu pengeringan yang relatif singkat.

\section{KAJIAN LITERATUR DAN PEGEMBANGAN HIPOTESIS (JIKA ADA)}

\subsection{Pengering Efek Rumah Kaca}

Pengering Efek Rumah Kaca adalah alat pengering berenergi surya yang memanfaatkan efek rumah kaca yang terjadi karena adanya penutup transaparan pada dinding bangunan serta plat absorber sebagai pengumpul panas untuk menaikkan suhu udara ruang pengering. Lapisan transparan memungkinkan radiasi gelombang pendek dari matahari masuk ke dalam dan mengenai elemen-elemen bangunan. Hal ini menyebabkan radiasi gelombang pendek yang terpantul berubah menjadi gelombang panjang dan terperangkap dalam bangunan karena tidak dapat menembus penutup transparan sehingga menyebabkan suhu menjadi tinggi.

\subsection{Perpindahan Panas}

Perpindahan panas yang terjadi pada proses pengeringan adalah perpindahan panas secara konduksi, konveksi dan radiasi.Perpindahan panas secara konduksi dapat dituliskan seperti pada (Incropera, 1996):

$$
q=-k A \frac{\Delta T}{\Delta x}
$$

Perpindahan panas secara konveksi secara umum dapat dituliskan dengan menggunakan persamaan:

$$
q_{\text {conv }}=h . A . \Delta t
$$

Nilai konstanta perpindahan panas konveksi $(k)$ mempunyai nilai yan berbeda bergantung jenis aliran dan nilai konduktivitas yang digunakan untuk mendapatkan harga dari koefisien konveksi $(h)$. Sedangkan perpindahan panas radiasi secara umum dapat ditulisakan dengan menggunakan persamaan.

$$
q_{\text {rad }}=\sigma A T^{4}
$$

Sedangkan nilai perpindahan panas secara radiasi antara dua buah plat datar bergantung pada view factor. Sebelum mencari nilai view factor-nya, mengikuti dahulu urutan dari rumus yang dituliskan pada persamaan $(5-8)$ berikut:

$$
\begin{gathered}
a=\left(\frac{\left(1+\bar{X}^{2}\right)\left(1+\bar{Y}^{2}\right)}{1+\bar{X}^{2}+\bar{Y}^{2}}\right)^{1 / 2} \\
b=\bar{X}\left(1+\bar{Y}^{2}\right)^{1 / 2} \tan ^{-1} \frac{\bar{X}}{\left(1+\bar{Y}^{2}\right)^{1 / 2}} \\
c=\bar{Y}\left(1+\bar{X}^{2}\right)^{1 / 2} \tan ^{-1} \frac{\bar{Y}}{\left(1+\bar{X}^{2}\right)^{1 / 2}} \\
d=\bar{X} \tan ^{-1} \bar{X}-\bar{Y} \tan ^{-1} \bar{Y}
\end{gathered}
$$

Sehingga hubungan nilai perpindahan panas secara radiasi antara dua pelat sejajar dan view factor dari permukaan $i$ ke permukaan $j$ dituliskan menggunakan persamaan:

\subsection{Laju Penguapan}

$$
F_{i j}=\frac{q_{i j}}{A_{i} J_{i}}
$$

Evaporasi secara umum dapat didefinisikan dalam dua kondisi, yaitu: (1) evaporasi yang berarti proses penguapan yang terjadi secara alami, dan (2) evaporasi yang dimaknai dengan proses penguapan yang timbul akibat diberikan uap panas (steam) dalam suatu peralatan.

Evaporasi dapat diartikan sebagai proses penguapan daripada liquid (cairan) dengan penambahan panas (Long, 1995). Panas dapat disuplai dengan berbagai cara, diantaranya secara alami dan penambahan steam. Adapun $q_{e}$ dapat di cari dengan persamaan (10) (Tiwari, 2010).

$$
\mathrm{q}_{\mathrm{e}}=0.016 \frac{\mathrm{k}_{\mathrm{v}}}{\mathrm{x}} \mathrm{c}\left(\mathrm{R}_{\mathrm{e}} \cdot \mathrm{P}_{\mathrm{r}}\right)^{\mathrm{n}} \cdot\left(\mathrm{P}_{\mathrm{Tp}}\right)-\left(\gamma \cdot \mathrm{P}_{\mathrm{Te}}\right)
$$

Sedangkan $\mathrm{M}_{\mathrm{ev}}$ adalah massa terevaporasi, yaitu panas yang diperlukan untuk evaporasi per panas spesifik dari proses dan dapat dituliskan menggunakan persamaan:

$$
\mathrm{M}_{\mathrm{ev}}=\frac{\mathrm{q}_{\mathrm{e}}}{\lambda}
$$

Dimana $\lambda$ udara yang digunakan adalah $2257 \mathrm{KJ} / \mathrm{kg}$ dan untuk mendapatkan hasil dari $\mathrm{q}_{\mathrm{e}}$ maka perlu dicari pula nilai Reynold number sesuai persamaan:

$$
\mathrm{R}_{\mathrm{e}}=\frac{\mathrm{V}_{\mathrm{a}} \cdot \mathrm{D}_{\mathrm{h}}}{\vartheta_{\mathrm{a}}}
$$


$\mathrm{V}_{\mathrm{a}}$ adalah laju aliran udara, $\vartheta_{\mathrm{a}}$ adalah viskositas udara, $\mathrm{Dh}$ adalah diameter hidraulic dalam satuan meter dan adalah lebar bak pengering. Bilangan Prandtl (Pr) yang digunakan didapatkan dengan cara interpolasi dari tabel A.4 thermophysical properties of gases at athmospheric pressure.

\subsection{Efisiensi Pengeringan dan Efisiensi Alat Pengering}

Efisiensi pengeringan adalah hasil perbandingan antara panas yang secara teoritis yang dibutuhkan $(Q)$ dengan penggunaan panas yang sebenarnya dalam pengeringan $(q)$, dengan kata lain evaluasi ini lebih kepada proses pengeringan (Kristiawan Budi dkk, 2008). Efisiensi pengeringan dapat dituliskan dengan menggunakan persamaan:

$$
\eta_{p}=\frac{Q}{q} \times 100 \%
$$

Sedangkan efisiensi alat pengering dievaluasi berdasarkan panas yang dihasilkan dalam rumah kaca dimana jumlah kalor yang digunakan $(Q)$ dibagi dengan energi input $\left(Q_{i n}\right)$. Energi input pada rumah kaca dapat dituliskan dalam persamaan:

$$
Q_{\text {in }}=I_{(t)} \cdot \text {. A. } t
$$

$I_{(t)}$ adalah rata - rata intensitas matahari, A adalah luas bak pengering dan $t$ adalah waktu dalam menit. Dengan demikian efisiensi alat pengering dituliskan dengan menggunakan persamaan: (Kristiawan Budi dkk, 2008).

$$
\eta_{a}=\frac{Q}{Q_{\text {in }}} \times 100 \%
$$

\subsection{Pengurangan Kadar Air Jagung}

Massa jagung yang diteliti setiap harinya di timbang dengan timbangan analitik setiap harinya pada awal dan akhir proses pengeringan. Massa jagung awal yang akan diteliti sudah ditentukan terlebih dahulu yaitu $5 \mathrm{~kg}$. Pengurangan air dengan menggunakan basis basah (Ekechukwe, 1997). Dapat dituliskan menggunakan persamaan:

$$
M_{w b}=\frac{w_{0}-w_{d}}{w_{0}} \times 100 \%
$$

\section{METODE KEGIATAN}

\subsection{Desain Geometri Alat}

Alat yang digunakan pada sistem pengering tenaga matahari adalah alat pengering dengan mengunakan sistem rumah kaca dengan tambahan batu sebagai penyimpan panas. Berikut ini adalah desain dari masing-masing bagian dari alat pengering yang digunakan

\section{$\checkmark$ Pengumpul Panas}

Pengumpul panas terbuat dari kaca pelat datar setebal $5 \mathrm{~mm}$ dan alumunium pelat datar setebal 3 mm sebagai bak pengering

\section{$\checkmark$ Kondensor}

Kondensor pada pengering berbentuk plat datar dengan ukuran $1 \mathrm{~m}$ x 0,8 $\mathrm{m}$ dengan kemiringan sebesar $60^{\circ}$ dengan bahan terbuat dari kaca bening tebal $5 \mathrm{~mm}$

\section{$\checkmark$ Cerobong (chimney)}

Cerobong (chimney) terbuat dari pipa PVC dengan dimensi tinggi $300 \mathrm{~mm}$ dan dengan diameter sebesar $100 \mathrm{~mm}$. Dimensi dari cerobong didapatkan dari literatur tentang pengering tipe rumah kaca dengan melakukan erbandingan (yayienda, 2013).

$\checkmark \quad$ Ruang Pemanas

Ruang pemanas terbuat dari kaca bening dengan volume $1 \mathrm{~m}$ x $0,8 \mathrm{~m}$ x $0,6 \mathrm{~m}$ tebal $5 \mathrm{~mm}$ dimana didalam ruang kaca tersebut terdapat bak pengering dengan ukuran $1 \mathrm{~m} \times 0,8 \mathrm{~m}$.

$\checkmark \quad$ Penyimpan panas

Media penyimpan panas yang digunakan adalah batu kali dengan diameter $40 \mathrm{~cm}$ s.d $50 \mathrm{~cm}$ dan dicat warna hitam.

Gambar 1 menunjukkan skema geometri pengering, gambar 2 menunjukan desain pengering dilengkapi dengan batu sebagai media penyimpan panas dan pada dan Tabel 1 menunjukkan variasi yang digunakan dalam menguji performansi alat pengering tipe hybrid.

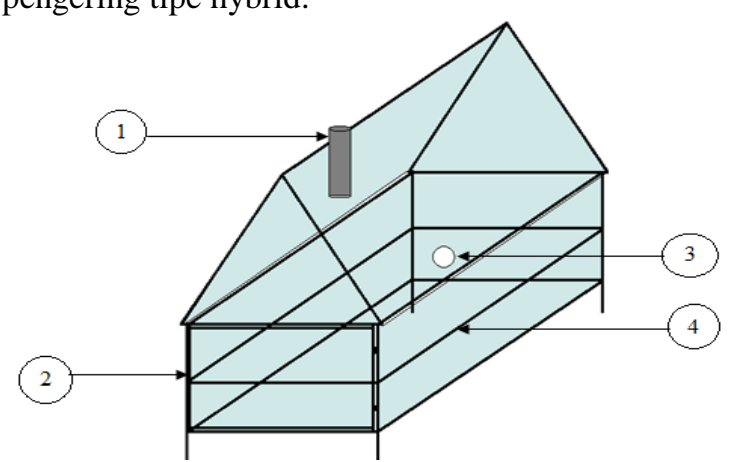

1. Cerobong Sirkulasi Udara (Cerobong 1)

2. Pintu Kedap Udara

3. Cerobong Variasi Bukaan (Cerobong 2)

4. Bak Pengering Gambar 1. Desain alat ERK

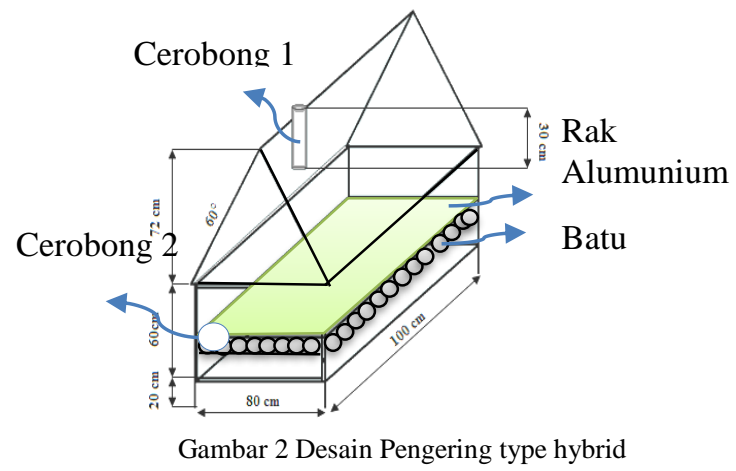

Variasi pengeringan adalah menggunakan bak kaca dan bak alumunium dengan bukaan pada cerobong 2 adalah $0 \%, 50 \%$ dan $100 \%$ dengan tambahan batu sebagai media penyimpan panas. Jagung awal yang dimasukkan pada pengering mempunyai kandungan air sebanyak $21 \%$. Pengujian kadar air dilakukan dengan alat ukur moisture tester.

\subsection{Pengambilan Data}

Pengambilan data dilakukan dengan dengan memasukkan bahan uji dengan masa $5 \mathrm{~kg}$ kemudian dilakukan pengukuran kadar air bahan uji sebelum dan setelah pengeringan. Pengambilan data dilakukan selama 9 jam setiap hari selama 18 hari 
pengujian. Data yang diambil adalah kelembapan relatif pengering, suhu dalam ruang pengering, suhu dalam dan luar atap pengering, bak pengering bagian atas dan bawah, suhu jagung, kelembaban relatif pada ruang pengering dan lama panas yang tersimpan dalam alat pengering ERK dengan adanya tambahan variasi batu sebagai media peyimpan panas. Pada gambar 3 ditampilkan titik-titik pengambilan data selama pengukuran.

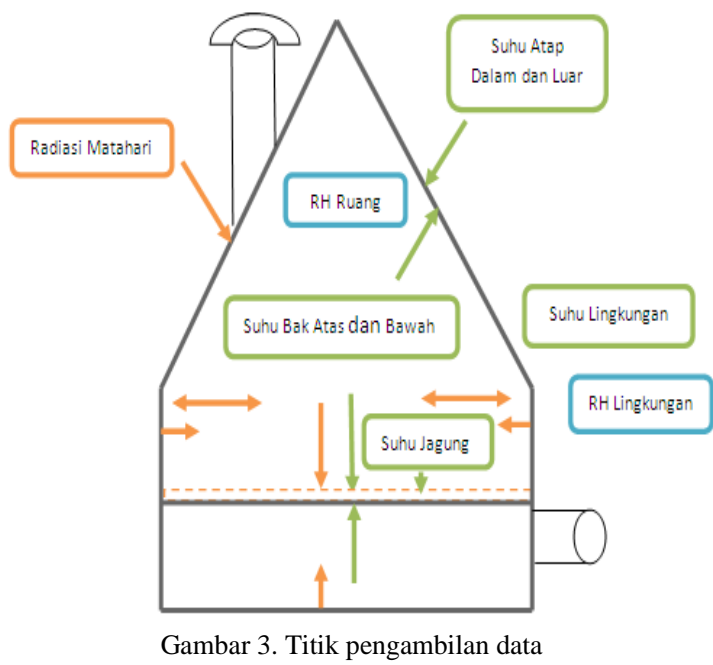

\section{HASIL DAN PEMBAHASAN}

\subsection{Hasil Uji Lapangan}

Berdasarkan data yang telah diambil, perbedaan suhu pada setiap titik pengukuran dapat dilihat pada Gambar 4.1 berikut ini

pengukuran tersebut terlihat bahwa nilai intensitas yang besar pada siang hari rata-rata terdapat pada pengukuran setiap jam 13.00 WITA dengan nilai intensitas tertingginya sebesar 779 $\mathrm{W} / \mathrm{m}^{2}$ dan nilai intensitas terendahnya sebesar $30 \mathrm{~W} / \mathrm{m}^{2}$ yaitu pada jam 17.00 WITA.

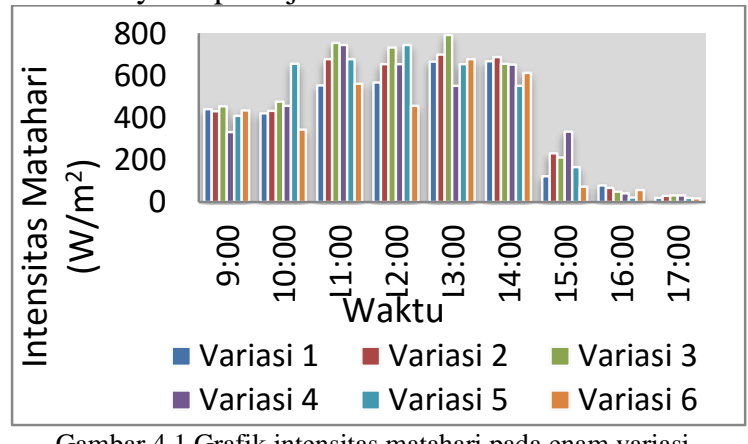

Gambar 4.1 Grafik intensitas matahari pada enam variasi

\subsection{Suhu dan Kelembaban Relatif}

1. Pengering ERK Variasi 1

Data pengukuran suhu dan kelembaban relatif pada enam variasi pengeringan dapat dilihat pada grafik berikut:

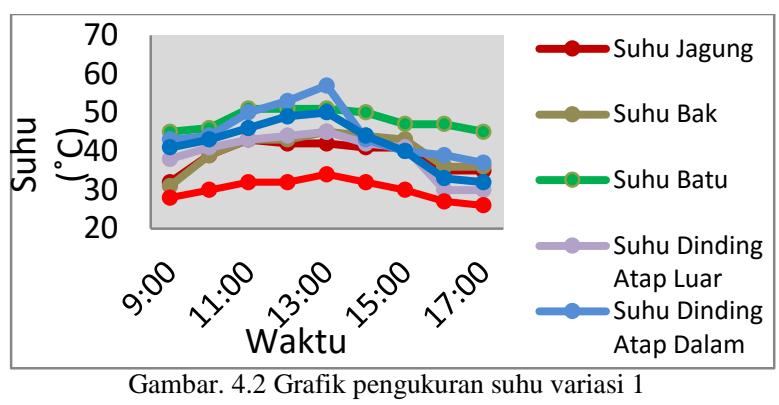

Dari gambar pengukuran suhu pada variasi 1 terlihat bahwa suhu yang di dapatkan mengikuti pola suhu pada intensitas matahari dan berbanding terbalik dengan nilai kelembaban relatifnya.

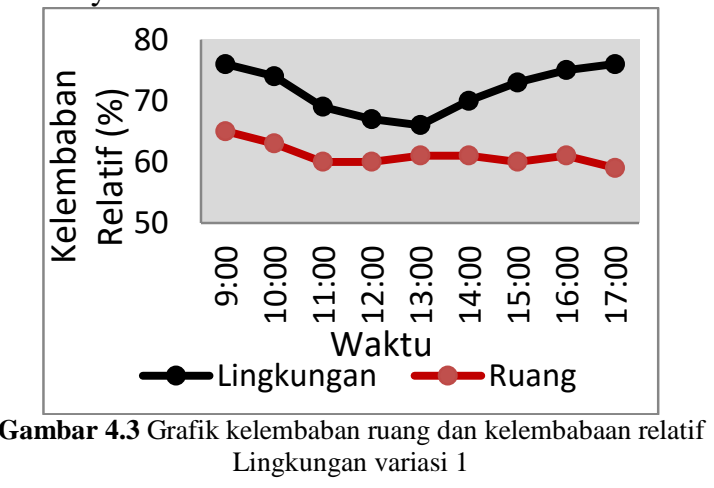

Untuk kelembaban relatif lingkungan dan data kelembaban ruang pada pengering rumah kaca variasi 1 terlihat lebih rendah dari kelembaban lingkungannya.

\section{Pengering ERK Variasi 2}

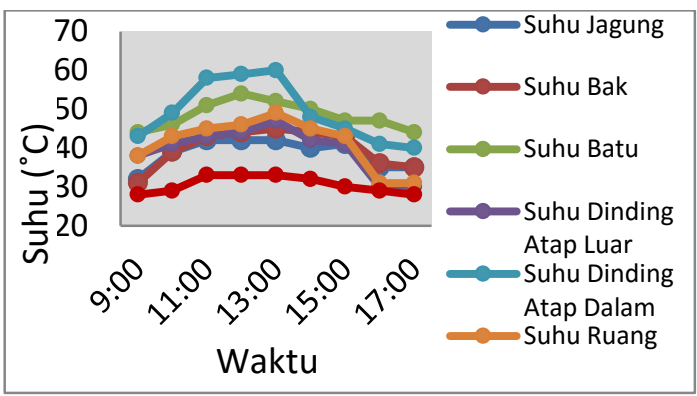

Gambar 4.4 Grafik pengukuran suhu pada variasi 2

Uji coba lapangan juga dilakukan selama tiga hari masing-masing mewakili satu variasi pada ujicoba lapangan. Pengukuran suhu-suhu pada variasi 2 dimana suhu tertinggi terdapat pada bak pengering bagian atas pada jam 13.00 WITA dan suhu terendah pada suhu lingkungan pada jam 17.00 WITA. 


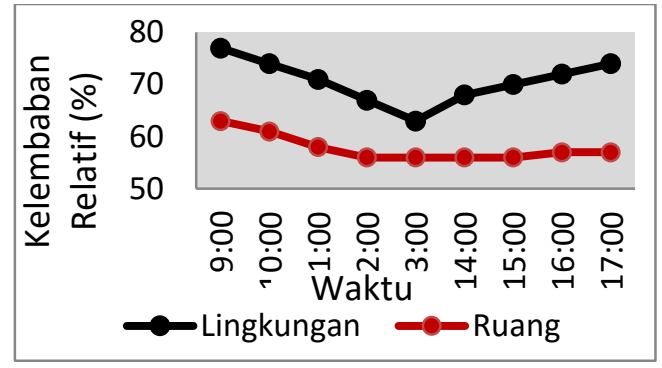

Gambar 4.5 Grafik kelembaban relatif lingkungan dan kelembaban relatif ruang pengering variasi 2

Pada Gambar 4.10 terlihat bahwa kelembaban ruang tetap pada nilai terendahnya sedangkan kelembaban relatif lingkungan mengalami kenaikan sampai dengan $72 \%$ pada jam 17.00 WITA.

\section{Pengering ERK Variasi 3}

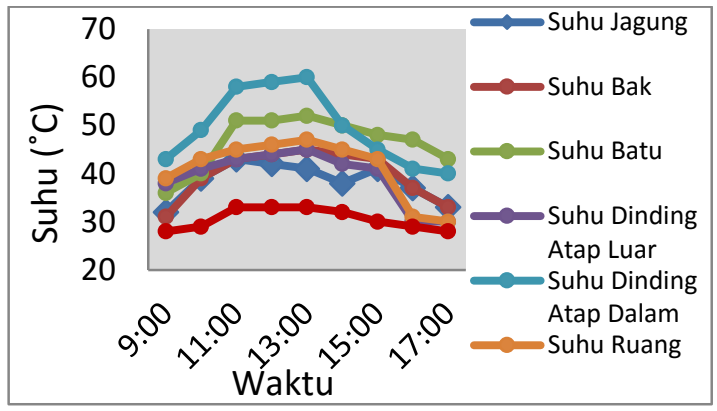

Gambar 4.6 Grafik pengukuran suhu pada pengering variasi 3

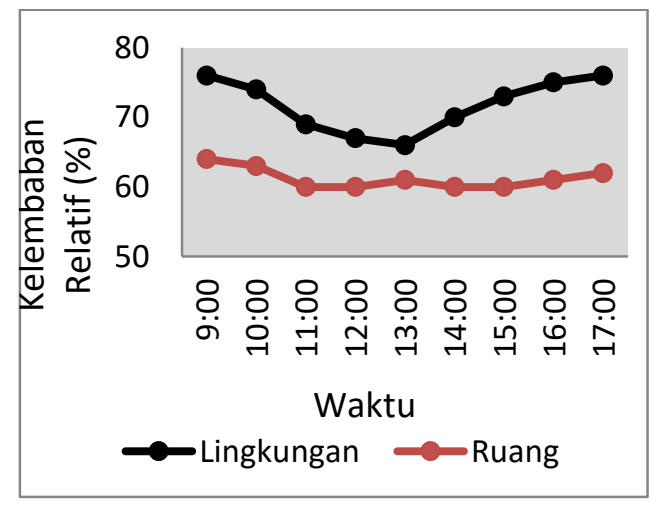

Gambar 4.7 Grafik kelembaban relatif lingkungan dan kelembaban ruang pengering variasi 3

Pada variasi 3 terlihat bahwa kelembaban ruang pengering tetap pada nilai terendahnya yaitu pada $56 \%$ walaupun pada waktu yang sama nilai kelembaban lingkungannya naik sampai $76 \%$.
4. $\quad$ Pengering ERK Variasi 4

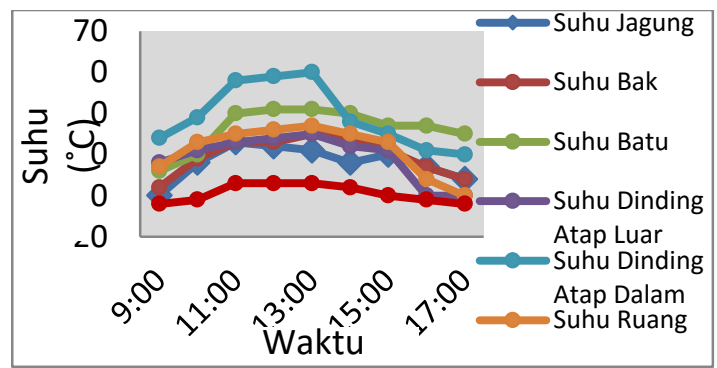

Gambar 4.8 Grafik pengukuran suhu pengering variasi 4

Hasil pengukuran sushu-suhu pada variasi 4 dapat dilihat pada, Gambar 4.9 dimana suhu -suhu tertinggi terdapat pada bak pengering dan suhu terendahnya pada atap bagian luar

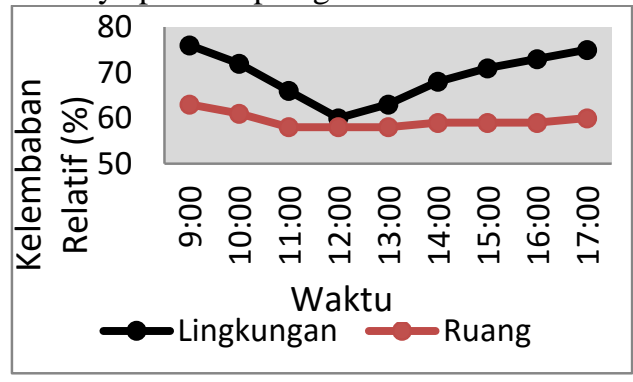

Gambar 4.9 Grafik kelembaban relatif lingkungan dan kelembaban ruang pengering variasi 4

Untuk kelembaban relatif ruang pada variasi 3 berada pada nilai yang lebih rendah dari pada nilai kelembaban pada variasi 1 dan 2 yaitu $52 \%$ sedangkan untuk nilai kelembaban lingkungannya mengalami kenaikan lagi setelah jam 14.00 WITA.

\section{Pengering ERK Variasi 5}

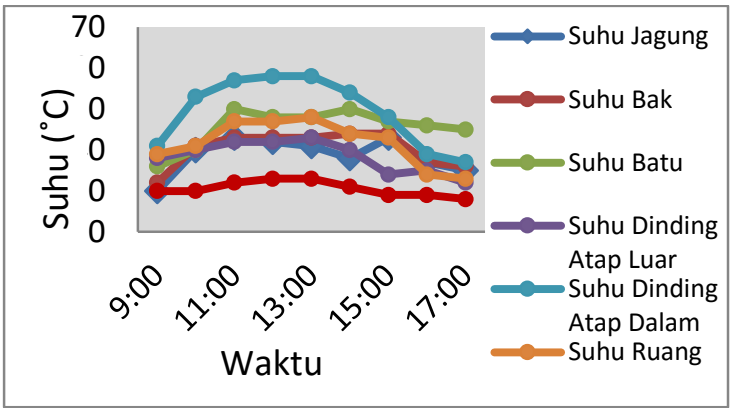

Gambar 4.10 Grafik pengukuran suhu pada pengering variasi 5

Pengukuran suhu pada variasi 5 dapat dilihat pada gambar 4.10 dimana suhu tertinggi hanya 42 ${ }^{\circ} \mathrm{C}$ pada suhu ruangnya dan suhu lingkungannya mencapai $28{ }^{\circ} \mathrm{C}$ pada jam 13.00 WITA hal ini disebabkan karena bukaan pada variasi ini adalah bukaan $0 \%$ sehingga mempengaruhi nilai kelembaban di dalam pengering. 


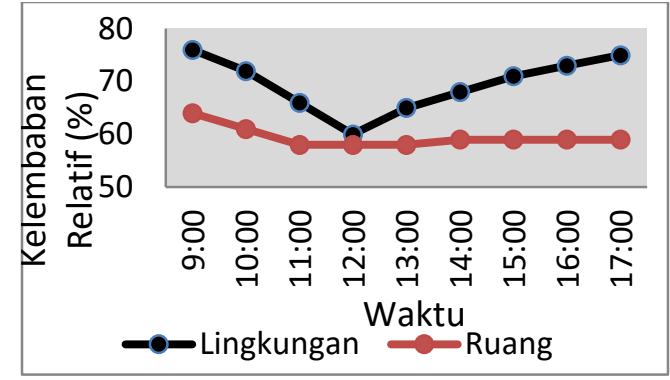

Gambar 4.11 Grafik kelembaban relatif lingkungan dan kelembaban ruang pengering variasi 5

Untuk kelembaban relatif ruang dan kelembaban relatif lingkungan pada variasi ini terlihat bahwa pada jam 12.00 nilainya hampir sama yaitu $65 \%$ untuk kelembaban ruang dan $59 \%$ kelembaban lingkungannya

6. Pengering ERK Variasi 6

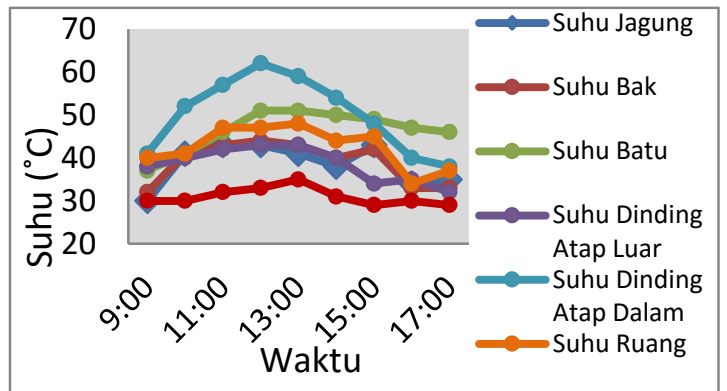

Gambar 4.12 Grafik pengukuran suhu pada pengering variasi 6 Dari grafik 4.12 terlihat bahwa suhu pada bak aluminium variasi 6 memiliki nilai yang lebih besar dari pada 5 variasi lainnya yaitu mencapai $64^{\circ} \mathrm{C}$ pada jam 12.00 sampai dengan jam 13.00. hal ini menyebabkan variasi ini terlihat lebih baik dari pada 5 variasi lainnya.

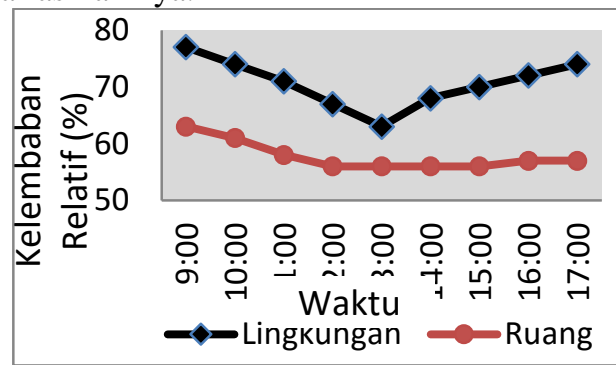

Gambar 4.13 Grafik kelembaban relatif lingkungan dan kelembaban ruang pengering variasi 6

\subsection{Perpindahan Panas}

\begin{tabular}{|c|c|c|c|c|c|}
\hline \multicolumn{6}{|c|}{ Efisiensi pengeringan (\%) } \\
\hline \multicolumn{7}{|c|}{ Variasi } \\
\hline 1 & 2 & 3 & 4 & 5 & 6 \\
\hline $67 \%$ & $56 \%$ & $70 \%$ & $56 \%$ & $52 \%$ & $67 \%$ \\
\hline \multicolumn{6}{|c|}{ Efisiensi alat pengering (\%) } \\
\hline \multicolumn{6}{|c|}{ Variasi } \\
\hline 1 & 2 & 3 & 4 & 5 & 6 \\
\hline $85 \%$ & $75 \%$ & $72 \%$ & $69 \%$ & $69 \%$ & $69 \%$ \\
\hline
\end{tabular}

Hasil perpindahan panas konduksi, konveksi dan radiasi dapat dilihat pada Tabel 2 sampai dengan 4.

\begin{tabular}{ccc}
\hline Variasi & Tempat & $\begin{array}{c}\text { q konduksi } \\
(\mathrm{W})\end{array}$ \\
\hline \multirow{2}{*}{1.} & Atap (Dalam - Luar) & 1058.4 \\
& Bak (Atas - Bawah) & 20200 \\
2. & Atap (Dalam - Luar) & 1572.48 \\
& Bak (Atas - Bawah) & 22893.33 \\
3. & Atap (Dalam - Luar) & 1602.72 \\
& Bak (Atas - Bawah) & 18180 \\
4 & Atap (Dalam - Luar) & 2916,67 \\
& Bak (Atas - Bawah) & 17506.67 \\
5 & Atap (Dalam - Luar) & 1617.84 \\
& Bak (Atas - Bawah) & 12793.33 \\
6 & Atap (Dalam - Luar) & 1663.2 \\
& Bak (Atas - Bawah) & 13130 \\
\hline
\end{tabular}

Tabel 2. Nilai q konduksi pada enam variasi pengering

\begin{tabular}{cc}
\hline Variasi & q radiasi $(\mathrm{W})$ \\
\hline 1. & 779.6 \\
2 & 789.1 \\
3 & 792.6 \\
4 & 786.5 \\
5 & 759.9 \\
6 & 797.1 \\
\hline
\end{tabular}

Tabel 3. Nilai q konveksi pada enam variasi pengering

\begin{tabular}{|c|c|c|}
\hline Variasi & Tempat & $\begin{array}{c}\text { q konveksi } \\
(\mathrm{W})\end{array}$ \\
\hline \multirow[t]{3}{*}{1.} & Bak - Ruang & 383.7 \\
\hline & Atap dalam - Ruang & 2.3 \\
\hline & Atap luar - Lingkungan & 2.0 \\
\hline \multirow[t]{3}{*}{2.} & Bak - Ruang & 230.2 \\
\hline & Atap dalam - Ruang & 5.9 \\
\hline & Atap luar - Lingkungan & 1.7 \\
\hline \multirow[t]{3}{*}{3.} & Bak - Ruang & 230.2 \\
\hline & Atap dalam - Ruang & 7.95 \\
\hline & Atap luar - Lingkungan & 1.6 \\
\hline \multirow[t]{3}{*}{4} & Bak - Ruang & 268.6 \\
\hline & Atap dalam - Ruang & 7.9 \\
\hline & Atap luar - Lingkungan & 1.7 \\
\hline \multirow[t]{3}{*}{5} & Bak - Ruang & 246.6 \\
\hline & Atap dalam - Ruang & 7.4 \\
\hline & Atap luar - Lingkungan & 2.8 \\
\hline \multirow[t]{3}{*}{6} & Bak - Ruang & 739.6 \\
\hline & Atap dalam - Ruang & 6.9 \\
\hline & Atap luar - Lingkungan & 3.9 \\
\hline
\end{tabular}

Tabel 4. Nilai q radiasi pada enam variasi pengering 


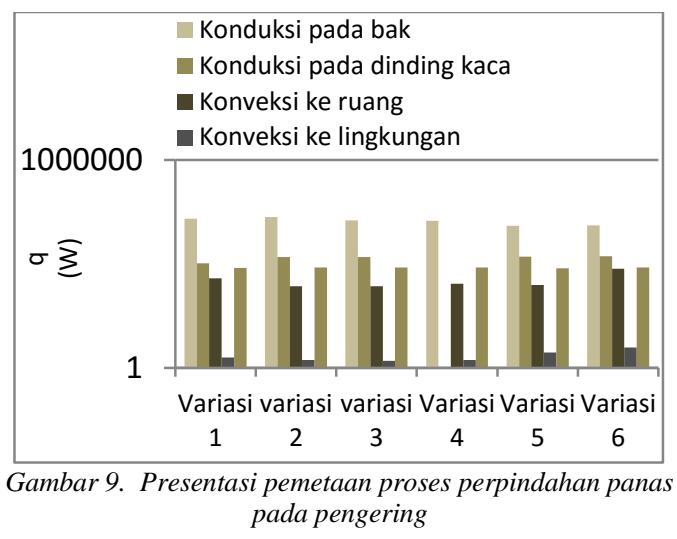

Dari prosentase pemetaan pada Gambar 9 dapat dilihat bahwa perpindahan panas terbesar pada proses pengeringan efek rumah kaca adalah melalui konduksi. Dimana perpindahan panas konduksi pada bak pengering dari bahan alumunium memiliki nilai tertinggi dan juga menaikan nilai konveksi dalam ruang.

\subsection{Laju Penguapan}

Laju penguapan terbaik adalah pada variasi 6 dengan bukaan cerobong $100 \%$ dan menggunakan batu sebagai media penyimpan panas. proses penguapan pada variasi 6 , lihat pada tabel 5 dibawah ini:

Tabel 5. Laju penguapan pada variasi 6

\begin{tabular}{ccc}
\hline T (waktu) & Qe $\left(\mathrm{J} / \mathrm{m}^{2} . \mathrm{s}\right)$ & Mev $($ gram $)$ \\
\hline 09.00 & 19611.76 & 868.931 \\
10.00 & 19721.4 & 873.788 \\
11.00 & 36224.63 & 1604.99 \\
12.00 & 34089.2 & 1510.38 \\
13.00 & 33897.46 & 1501.88 \\
14.00 & 21981.6 & 973.93 \\
15.00 & 22106.77 & 979.476 \\
16.00 & 17992.87 & 797.203 \\
17.00 & 5464.909 & 242.132 \\
\hline
\end{tabular}

Dari tabel 5 menghasilkan nilai Qe dan nilai $\mathrm{M}_{\mathrm{ev}}$ terbesar pada pukul 11.00 WITA.

\subsection{Efisiensi}

Efisiensi adalah ukuran tingkat penggunaan alat pada proses pengeringan.

Tabel 6. Efisiensi pengeringan dan efisiensi alat pengering

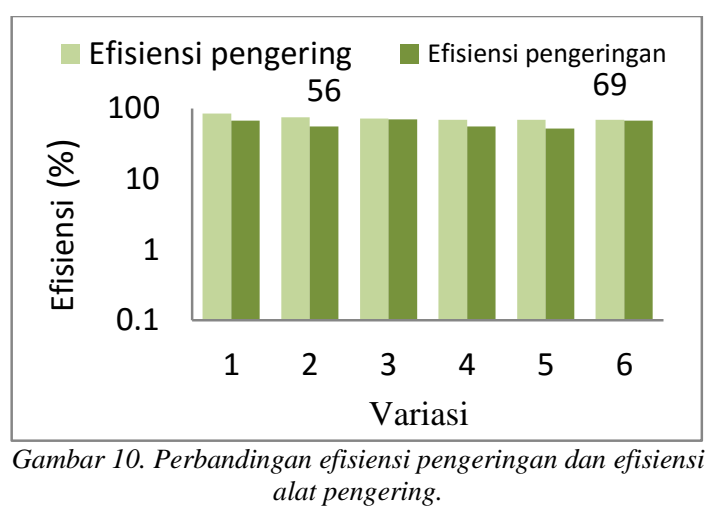

Dari Gambar 11 dapat dilihat bahwa efisiensi pengeringan terbaik adalah pada variasi 3, sedangkan untuk efisiensi alat pengering terbaik adalah pada variasi 1 .

\subsection{Laju pengeringan}

Kadar air jagung pipilan sesuai standart SNI adalah 13-14\%. Lama pengeringan adalah 8 jam pengeringan.

\begin{tabular}{ccccc}
\hline Jenis & \multicolumn{2}{c}{ Massa $(\mathrm{kg})$} & \multicolumn{2}{c}{ Kadar air (\%) } \\
\cline { 2 - 5 } pengeringan & Sebelum & Sesudah & Sebelum & Sesudah \\
\hline Variasi 1 & 5 & 3.8 & 21 & 13.4 \\
Variasi 2 & 5 & 3.8 & 21 & 13.4 \\
Variasi 3 & 5 & 3.5 & 21 & 13.1 \\
Variasi 4 & 5 & 3.6 & 21 & 13.2 \\
Variasi 5 & 5 & 3.3 & 21 & 12.9 \\
Variasi 6 & 5 & 3.2 & 21 & 12.6 \\
\hline
\end{tabular}

Tabel 7 Massa dan kadar air jagung

Setelah mengetahui Laju perpindahan panas yang berguna untuk penguapan kadar air (Qe) dan massa terevaporasi $\left(\mathrm{M}_{\mathrm{ev}}\right)$ pada setiap variasi kemudian dibandingkan dengan data laju pengeringan yang di ambil saat penelitian dalam hal ini penurunan massa terhadap waktu.

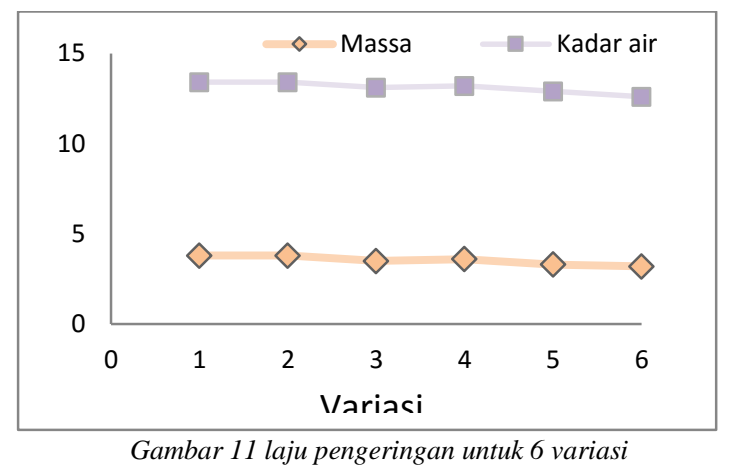

\subsection{Panas yang Tersimpan}

Panas yang tersimpan diukur setelah proses pengeringan yaitu dari pukul 17.00 sampai dengan 22.00 WITA. Dari hasil pengukuran yang dilakukan di peroleh data variasi pengeringan penyimpan panas terbaik dari adanya batu sebagai media penyimpan panas adalah pada variasi 6 , dengan suhu 
batu tertinggi $39^{\circ} \mathrm{C}$ diukur pada pukul 18.00 dan 19.00 WITA artinya memiliki tingkat penyimpan panas yang lebih baik akan tetapi panas produk jagung yang dikeringkan hanya $33^{\circ} \mathrm{C}$ dengan bukaan cerobong $100 \%$. Data tersebut dapat dilihat pada gambar 13 berikut.

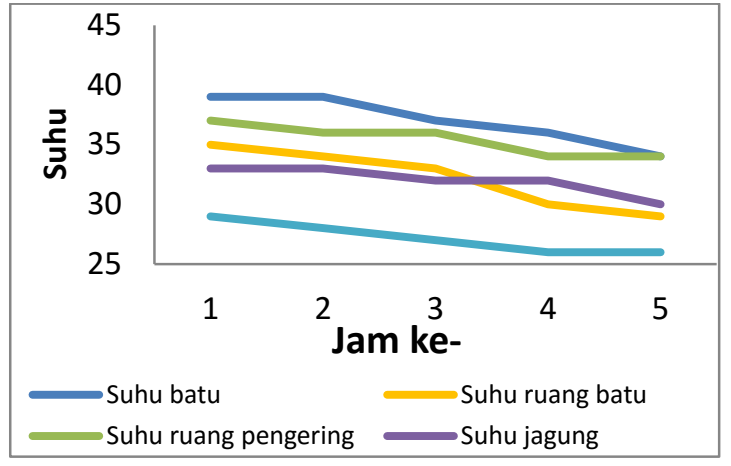

Gambar 12. Grafik suhu setelah proses pengeringan variasi 6

\section{KESIMPULAN}

Kesimpulan yang di dapatkan dari penelitian ini berdasarkan data - data yang telah diolah adalah

- Variasi bukaan cerobong mempengaruhi kelembaban relatif di dalam ruang pengering dimana semakin besar bukaan cerobong maka semakin baik sirkulasi udara di dalam pengering sehingga selain mengurangi kelembaban relatif di dalam ruang pengering juga dapat mempercepat laju penguapan

- Perpindahan panas terbesar pada pengering tipe rumah kaca adalah perpindahan panas konduksi pada variasi 2 yaitu sebesar $22893.33 \mathrm{~W}$. perpindahan panas konveksi dan perpindahan panas radiasi terbesar adalah pada variasi 6 yaitu sebesar 739.6 W dan radiasi 797.1 W

- Laju perpindahan panas yang berguna untuk penguapan kadar air (Qe) dan massa terevaporasi $\left(\mathrm{M}_{\mathrm{ev}}\right)$ terbaik sesuai analisis adalah pada variasi 6 dimana Qe pada pukul 11.00 WITA adalah 2344.51J/m².s dan Mev 1039.19 gram.

- Efisiensi pengeringan terbaik adalah pada variasi 3 dengan bukaan $100 \%$ menggunakan bak kaca yaitu $70 \%$ sedangkan efisiensi alat pengering terbaik pada variasi 1 dengan bukaan $0 \%$ menggunakan bak kaca yaitu $85 \%$.

- Massa awal jagung sebelum dilakukan proses pengeringan adalah $5 \mathrm{~kg}$, variasi pengeringan yang mengalami penurunan massa terbesar adalah pada variasi 6 yaitu $3,2 \mathrm{~kg}$ dan untuk penurunan kadar air akhir jagung yang paling besar adalah pada variasi 6 yaitu 12,6\% yang artinya nilai tersebut melewati $13 \%$ sesuai standart SNI 01-03920-1995, untuk itu pengeringan jagung menggunakan alat pengering efek rumah kaca hanya membutuhkan waktu 8 jam pengeringan.

- Lama penyimpanan terbaik adalah pada variasi 6 dengan suhu batu $39^{\circ} \mathrm{C}$ diukur pada pukul 18.00 dan 19.00 WITA, dengan panas produk jagung yang dikeringkan adalah $30^{\circ} \mathrm{C}$ pada pukul 22.00 WITA.

\section{DAFTAR PUSTAKA}

Badan Meteorologi klimatologi dan geofisika (BMKG). 2014, Data radiasi matahari, suhu lingkungan wilayah bone bolango dan kelembaban lingkungan wilayah bone bolango, tanggal 10 Februari - 20 Maret 2014.

Badan Pusat Informasi Jagung. 2013, Produksi Jagung di Gorontalo. Artikel diakses tanggal 12 Januari 2014 pukul 11.10 WITA http://bpij.gorontalo.go.id.

Badan Meteorologi klimatologi dan geofisika (BMKG). 2014, Iklim di wilayah Gorontal, Artikel diakses tanggal 12 Januari 2014 pukul 11.00 WITA.

http://bmkg.gorontalo.go.id.

Badan Pusat Statistik Gorontalo (BPS). 2014. Rata-rata harga jagung hibrida di Gorontalo tahun 2013 - 2014.

http://bps.gorontalo.go.id.

Yayienda Nibras. 2013. Studi Eksperimental Sistem Pengering Tenaga Matahari Tipe Rumah Kaca Dengan Variasi Jarak Cermin Dalam Pengering. Surabaya.

Putri Indriyati. 2013, Studi eksperimental system pengering tenaga surya menggunakan tipe green house dengan kotak kaca. Surabaya.

Titahelu Nicolas. 2010, Eksperimen Pengaruh Beban PanasTerhadap Karakteristik Perpindahan PanasOven Pengering Cengkih. Jurnal Teknologi, Volume 7 Nomor 1, 2010; 744 -750.

Tiwari, Anwar, 2000. Evaluation Of Convective Heat Transfer Coe $\bullet$ Cient In Crop Drying Under Open Sun Drying Conditions.

Incropera, Frank P. dan Dewitt, David P. Fundamentals of Heat and Mass Transfer. United States: John Willey \& Sons. 1996.

Ekechukwe, O.V. 1997. Review of solar-energy drying systems I: an overview of drying principles and theory. Energy Conversion and Management vol. 40 page593-613.

Setiawan Budi dkk. 2008, Analisis performansi prototipe pengering jamur kuping dengan memanfaatkan efek rumah kaca dan energi suplemen dari biobriket limbah log bag, Mekanika vol 7 no 1. 